\title{
Effect of Principal Supervision on Teacher Pedagogic Competencies
}

\author{
Aswinda, Arifuddin Siraj, Saprin \\ Pendidikan Agama Islam Pascasarjana UIN Alauddin, Makassar, Indonesia \\ Email: aswindarahman@gmail.com
}

(Diterima: 15-Maret-2019; di revisi: 19-April-2019; dipublikasikan: 30-Juni-2019)

\begin{abstract}
The research aims to Effect of Principal Supervision on Teacher Pedagogic Competencies at Public Elementary School 237 Aletellue in Soppeng Regency.This research use quantitative methodology with correlational ex post facto design to explain the research questions. To understand the issue, this research use methodological approach (quantitative-positivistic) and scientific approach (pedagogic and psychological). The participants of this reseach are 13 teachers at Publich Elementary School 237 Aletellue. The data were gathered using survey and dokumentasi, and then analysed through descriptive statistic with hypothesis testing using correlation and linear regression coefficient. The research reveals some key findings. The first finding shows that the supervision of principals shows a comparison of the competence of pedagogic teachers. This, seen from every activity of the teacher who is able to be effective in improving the competencies possessed. Helps develop science with innovation and creativity.
\end{abstract}

Keywords: Supervision, Principal, Superintendent, Teachers’ Pedagogical Competence.

\section{INTRODUCTION}

The teacher has a strategic role in the field of education (Badia \& Chumpitaz-Campos, 2018; Dobber, Zwart, Tanis, \& van Oers, 2017; Koivuniemi, Järvenoja, \& Järvelä, 2018; Munthe \& Rogne, 2015; Tapola, 2011). In order to become an expected teacher it is not easy, because it must have many competencies, including pedagogical competencies (Akib \& Saleh, 2015; Amaliyah, Akib, \& Tambe, 2015; Megawati \& Kahar, 2017). Pedagogic competencies, namely competencies that master learning and get to know students (Dahlan, Iriawan, \& Hamdan, 2017; Darwis, Batari, Salam, Kasmita, \& Baharuddin, 2019; Fransiska, 2016). The quality of learning is greatly influenced by the pedagogical competence of teachers in managing students, so teachers need to be continuously nurtured and trained to improve their pedagogical competencies, one of which is education supervision.

Educational supervision is supervisory activities carried out by superiors to their subordinates by helping to improve their competence in developing quality learning processes. Supervision in the learning process is very important and influential in improving teacher pedagogical competence. Supervision must be done really to help and solve problems faced by the teacher (Altunay, Arlı, Öz, \& Yalçınkaya, 2013).

According to Government Regulation Number 74 of 2008 concerning Teachers Article 54 paragraph 8 point $d$ states that teachers appointed in the position of supervisor of the education unit carry out the task of mentoring and professional training of teachers and supervisory duties. The task of supervision in question is to carry out academic and managerial supervision

Copyright ( 2019 Universitas Negeri Makassar. This is an open access article under the CC BY license (http://creativecommons.org/licenses/by/4.0/)

Number: (RISTEKDIKTI) 21/E/KPT/2018 
96 Jurnal Ilmiah Ilmu Administrasi Publik: Jurnal Pemikiran dan Penelitian Administrasi Publik
Volume 9 Number 1, January - June 2019. Page 95-100

activities. This is in line with the Regulation of the Minister of Administrative Reform and Bureaucracy Utilization Number 14 of 2016 concerning Amendments to the Regulation of the Minister of Administrative Reform and Bureaucracy Utilization Number 21 of 2010 concerning the Functional Position of School Supervisors and Credit Figures Chapter II Article 5 stating that the main tasks The school supervisor is carrying out academic and managerial supervisory duties in the education unit which includes the preparation of supervision programs, implementation of guidance, monitoring, implementation of eight national standards of education, assessment and guidance and professional training of teachers, evaluation of the results of the supervision program implementation.

With the existing legal basis, supervision must be carried out based on the issuance of these regulations and carried out continuously so that teachers have good pedagogical competence in improving the quality and implementation of education. As in Law Number 20 of 2003 concerning the National Education System.

Based on the results of interviews with the principal at 237 Aletellue Elementary School in Soppeng District, the supervision carried out by the supervisor has gone well but still needs to be improved. The principal also urgently needs guidance from the supervisors of the target schools in improving the competencies of principals, teachers, other staff and students to be able to compete with other schools where he leads schools and teachers.

Based on the results of the above observations, it can be said that supervision is very important in improving the quality of the process of implementing education. Supervision if carried out continuously and continuously in accordance with the plan carried out by the principal and the school supervisor will improve the quality of the pedagogical competence of the teacher in managing students.

Supervised teachers are very helpful in improving their pedagogical competencies, namely managing students in the classroom including insights and understanding of the teacher towards students, developing curricula, arranging learning implementation plans, developing learning methods and strategies well, and being able to develop students' talents and interests.

\section{METHOD}

This type of research is classified as quantitative research through ex post facto method with methodological (positivistic-quantitative) and scientific (pedagogical and psychological) approaches. Respondents in this study were all teachers at 237 Aletellue Elementary School in Soppeng Regency, totaling 13 people. Data collection techniques used were questionnaires and documentation, while the analysis technique used was descriptive statistics by testing hypotheses using correlation analysis and linear regression.

\section{RESULT AND DISCUSSION}

\section{Data Analysis Results}

Testing the hypothesis of the effect of the principal's supervision on the pedagogical competence of teachers in 237 Aletellue Soppeng Public Elementary School is carried out using 
product moment correlation analysis and simple linear regression, then the determinant test to determine the effect of variable $\mathrm{X}$ (supervision of the principal) on $\mathrm{Y}$ (teacher's pedagogical competence).

Relationship, direction and level of relationship between variables X1 (supervision of the principal) with Y (pedagogical competence of teachers) at 237 Aletellue Elementary School in Soppeng Regency can be known using product moment correlation analysis. Calculations to obtain a correlation index number between variables X1 with variable $\mathrm{Y}$. The results of the analysis, can be seen in table 1 .

Table 1.

Relationship between Principal Supervision and Teacher Pedagogic Competence Correlations

\begin{tabular}{|ll|r|r|}
\hline & & Principal Supervision & \multicolumn{2}{|c|}{ Teacher's Pedagogic } \\
Competence
\end{tabular}

Based on the calculation and analysis, the product moment correlation value was obtained between the supervision of the principal and the teacher's pedagogical competence of 0.535 . Subsequent analysis, using a simple linear regression analysis. This analysis is used to predict changes in the value of the variable $\mathrm{Y}$ (teacher's pedagogical competence) if the variable $\mathrm{X} 1$ (supervision of the principal) is manipulated or increased. The results of the analysis, can be seen in table 2.

Table 2

Output Results of the Simple Regression Model of Principal Supervision and Teacher Pedagogic Competence

\begin{tabular}{|ll|r|r|r|}
\hline \multicolumn{2}{|l|}{ Model } & \multicolumn{2}{|c|}{ Coefficients $^{\mathbf{a}}$} \\
& \multicolumn{2}{|c|}{ Coeffardardized } & Standardized Coefficients \\
\cline { 2 - 5 } & \multicolumn{1}{|c|}{ B } & Std. Error & \multicolumn{1}{c|}{ Beta } \\
\hline \multirow{2}{*}{1} & (Constant) & 6.537 & 30.905 & \\
& Principal Supervision & .790 & .376 & .535 \\
\hline
\end{tabular}

a. Dependent Variable: Teacher's Pedagogic Competence

Based on the calculation and analysis, the regression equation is obtained, namely $\mathrm{Y}=$ $6.537+0.790 \mathrm{X}$. then, the Determination test is presented in table 3 . 
98 Jurnal Ilmiah Ilmu Administrasi Publik: Jurnal Pemikiran dan Penelitian Administrasi Publik Volume 9 Number 1, January - June 2019. Page 95-100

Table 3.

Results of the Large Output Effect of Principal Supervision on Teacher Pedagogic Competencies

Model Summary

\begin{tabular}{|l|r|r|r|r|}
\hline Model & \multicolumn{1}{|c|}{$\mathrm{R}$} & \multicolumn{1}{|c|}{ R Square } & Adjusted R Square & \multicolumn{1}{|c|}{ Std. Error of the Estimate } \\
\hline 1 & $.535^{\mathrm{a}}$ & .286 & .222 & 2.91760 \\
\hline
\end{tabular}

a. Predictors: (Constant), Principal Supervision

Based on these calculations, it can be seen that the effect of school principals' supervision on teacher pedagogical competencies is $29 \%$.

\section{Discussion}

Based on the results of statistical analysis shows that the supervision of the principal in increasing pedagogical competence of the teacher obtaining a correlation coefficient $(r)$ is 0.621 , while the coefficient of determination $\left(\mathrm{r}^{2}\right)$ is 0.286 . This shows that there is a strong influence between the supervision of the principal on the teacher's pedagogical competence and the contribution of the principal's supervision of teacher's pedagogical competence by $29 \%$. These results, indicate that supervision of the principal has an influence that cannot be separated from one another.

The results of this study indicate that the school principal's efforts in supervising the teacher will influence the pedagogical competence factor of the teacher in conducting the learning process for students. So that the teacher's professionalism in carrying out basic tasks and functions will develop faster and be able to keep up with the times. This is in accordance with the opinions of experts who revealed that supervision carried out by the school will help teachers to develop innovation and creativity they have. So as to be able to compete and be efficient in order to improve the quality of education (Amanda, Salam, \& Saggaf, 2017; Astuti, 2016, 2017; Da'i, 2009; Farida, 2017; Syamsiar, Saggaf, Salam, \& Ihsan, 2018)

\section{CONCLUSION}

Supervision of school principals has had a positive influence in order to improve the pedagogical competence of teachers at 237 Aletellue Elementary School in Soppeng Regency. This can be seen from every activity carried out by teachers who are able to improve creative and innovative competencies. 


\section{REFERENCES}

Akib, H., \& Saleh, S. (2015). Pengaruh Kepala Sekolah Sebagai Supervisor Terhadap Kinerja Guru Di Smk Negeri 7 Makassar. Jurnal Office, 1(2), 141-147.

Altunay, E., Arlı, D., Öz, Y., \& Yalçınkaya, M. (2013). Continuity in Educational Supervision: A Case Study. Procedia - Social and Behavioral Sciences, 106, 723-729. https://doi.org/https://doi.org/10.1016/j.sbspro.2013.12.083

Amaliyah, R., Akib, H., \& Tambe, M. N. (2015). Pengaruh Metode Mengajar Bervariasi Guru Terhadap Motivasi Belajar Siswa Pada Jurusan Administrasi Perkantoran Smk Negeri 1 Makassar. Jurnal Office, 1(2), 198-205.

Amanda, M. O., Salam, R., \& Saggaf, S. (2017). Pengaruh Supervisi Kepala Sekolah Terhadap Kinerja Guru Di SMK Negeri 1 Bungoro Kabupaten Pangkep. Prosiding Seminar Nasional Himpunan Sarjana Ilmu-Ilmu Sosial, 2, 149-154.

Astuti, S. (2016). Penerapan supervisi akademik untuk meningkatkan kompetensi guru dalam menyusun administrasi penilaian di sd laboratorium uksw. Scholaria: Jurnal Pendidikan Dan Kebudayaan, 6(1), 117-126.

Astuti, S. (2017). Supervisi akademik Untuk Meningkatkan Kompetensi Guru Di SD laboratorium UKSW. Scholaria: Jurnal Pendidikan Dan Kebudayaan, 7(1), 49-59.

Badia, A., \& Chumpitaz-Campos, L. (2018). Teachers learn about student learning assessment through a teacher education process. Studies in Educational Evaluation, 58, 1-7. https://doi.org/https://doi.org/10.1016/j.stueduc.2018.05.004

Da'i, W. (2009). Pengaruh Supervisi Kepala Sekolah dan Kompetensi Pedagogik Guru terhadap Kinerja guru SD Negeri Kec. Kersana Kab. Brebes. Universitas Negeri Semarang.

Dahlan, D., Iriawan, H., \& Hamdan, H. (2017). Pengaruh Kompetensi Manajerial Kepala Sekolah terhadap Kompetensi Sosial Guru Di SMA Negeri 11 Makassar. Jurnal Ilmiah Ilmu Administrasi Publik, 7(2), 59-68.

Darwis, M., Batari, U. D., Salam, R., Kasmita, M., \& Baharuddin, A. (2019). Pengaruh Kompetensi Profesional Guru Terhadap Kualitas Proses Pembelajaran Pada Paket Keahlian Administrasi Perkantoran Di SMK Negeri 1 Gowa. Jurnal Ad'ministrare: Jurnal Pemikiran Ilmiah Dan Pendidikan Administrasi Perkantoran, 5(2), 105-112.

Dobber, M., Zwart, R., Tanis, M., \& van Oers, B. (2017). Literature review: The role of the teacher in inquiry-based education. Educational Research Review, 22, 194-214. https://doi.org/https://doi.org/10.1016/j.edurev.2017.09.002

Farida, U. (2017). Analysis of Empowerment Program that was Implemented in Mamuju Regency East Sulawesi Indonesia. 149(Icest), 19-21.

Fransiska, C. (2016). Pengaruh Kompetensi Profesional Guru Terhadap Kualitas Proses Pembelajaran Pada Paket Keahlian Administrasi Perkantoran Di SMK Negeri 1 Bungoro Kabupaten Pangkep. Jurnal Office, 2(2), 163-172. 
100 Jurnal Ilmiah Ilmu Administrasi Publik: Jurnal Pemikiran dan Penelitian Administrasi Publik Volume 9 Number 1, January - June 2019. Page 95-100

Koivuniemi, M., Järvenoja, H., \& Järvelä, S. (2018). Teacher education students' strategic activities in challenging collaborative learning situations. Learning, Culture and Social Interaction, 19, 109-123. https://doi.org/https://doi.org/10.1016/j.lcsi.2018.05.002

Megawati, M., \& Kahar, F. (2017). Pengaruh Komunikasi Orang Tua Dengan Guru terhadap Peningkatan Kualitas Pembelajaran. Jurnal Office, 3(1), 33-42.

Munthe, E., \& Rogne, M. (2015). Research based teacher education. Teaching and Teacher Education, 46, 17-24. https://doi.org/https://doi.org/10.1016/j.tate.2014.10.006

Syamsiar, S., Saggaf, M. S., Salam, R., \& Ihsan, S. R. (2018). Implementation Of Supervision On Office Of Community Empowerment And Makassar City Village.

Tapola, A. M. (2011). Human dignity within teacher education: A matter of individualism, competitiveness, and strategic rationality. Teaching and Teacher Education, 27(8), 12451254. https://doi.org/https://doi.org/10.1016/j.tate.2011.07.004 